\title{
Effects of zinc sources and levels of zinc amino acid complex on growth performance, hematological and biochemical parameters in weanling pigs
}

\author{
Yi Zhang ${ }^{1}$, Terry Lynn Ward ${ }^{2}$, Fei Ji ${ }^{3}$, Chucai Peng ${ }^{1}$, Lin Zhu' ${ }^{1}$, Limin Gong ${ }^{1}$, and Bing Dong ${ }^{1 \text { ** }}$
}

\author{
* Corresponding Author: Bing Dong \\ Tel: +86-131-4619-5659, Fax: +86-10-62733688, \\ E-mail: dongbing@cau.edu.cn \\ 'State Key Laboratory of Animal Nutrition, China \\ Agricultural University, Beijing 100193, China \\ ${ }^{2}$ Zinpro Corporation, Eden Prairie, MN 55344, USA \\ ${ }^{3}$ Zinpro (Wuxi) Additives Bio-Technology Co., LTD., \\ Shanghai 201100, China \\ ORCID \\ Bing Dong \\ https://orcid.org/0000-0002-1150-3493
}

Submitted Oct 7, 2017; Revised Nov 4, 2017; Accepted Dec 18, 2017
Objective: The objective of the study was to investigate the effects of zinc amino acid complex (ZnAA) on growth performance, hematological and biochemical parameters in weanling pigs.

Methods: In Exp. 1, a total of 216 Duroc $\times$ Landrace $\times$ Large White weanling pigs were assigned randomly to 6 dietary treatments. Each treatment had 6 replicates (pens) with 6 pigs each. The diets were corn-soybean meal based with supplementation of $0,20,40,80,120 \mathrm{mg} \mathrm{Zn} / \mathrm{kg}$ from $\mathrm{ZnAA}$ or $40 \mathrm{mg} \mathrm{Zn/kg} \mathrm{from} \mathrm{feed-grade} \mathrm{zinc} \mathrm{sulfate.} \mathrm{The} \mathrm{experiment} \mathrm{lasted} 42$ days. In Exp. 2, a total of 180 weanling pigs were assigned randomly to 3 dietary treatments supplemented with 0, 80, or $800 \mathrm{mg} \mathrm{Zn} / \mathrm{kg}$ from $\mathrm{ZnAA}$.

Results: In Exp. 1, pigs fed 40 to $80 \mathrm{mg} Z \mathrm{Zn} / \mathrm{kg}$ from ZnAA had higher $(\mathrm{p}<0.05)$ average daily gain $(\mathrm{ADG})$ than the unsupplemented group during $\mathrm{d} 0$ to 14 . During $\mathrm{d} 0$ to 42 , the pigs fed 20 to $120 \mathrm{mg} \mathrm{Zn/kg}$ from ZnAA had increased (p<0.05) ADG. Pigs fed 20 to $120 \mathrm{mg} / \mathrm{kg} \mathrm{Zn}$ from $\mathrm{ZnAA}$ had lower feed:gain $(\mathrm{p}<0.05)$, increased the activity of serum $\mathrm{Cu}-\mathrm{Zn}$ superoxide dismutase on d 14, and increased serum Zn levels on d 42 ( $\mathrm{p}<0.05)$. In Exp. 2, pigs fed diets with $800 \mathrm{mg} \mathrm{Zn/kg} \mathrm{had} \mathrm{increased} \mathrm{average} \mathrm{daily} \mathrm{feed} \mathrm{intake} \mathrm{during} \mathrm{d} 15$ to 28 ( $\mathrm{p}<0.05$ ) compared to the unsupplemented group. During d 0 to 28 , the pigs fed supplemental $\mathrm{Zn}$ had increased $\mathrm{ADG}(\mathrm{p}<0.05)$. On d 14 and d 28, pigs fed supplemental $\mathrm{Zn}$ had higher the serum alkaline phosphatase activities $(\mathrm{p}<0.05)$. No significant differences were observed in the hematological parameters and organ indices.

Conclusion: Supplementation with 20 to $80 \mathrm{mg} / \mathrm{kg} \mathrm{Zn}$ from ZnAA improved the growth performance in weaned pigs. The piglets can tolerate up to $800 \mathrm{mg} / \mathrm{kg} \mathrm{Zn}$ from $\mathrm{ZnAA}$ with limited potential health effects.

Keywords: Zinc Amino Acid Complex; Weanling Pigs; Performance; Hematological Parameters; Biochemical Parameters

\section{INTRODUCTION}

Zinc $(\mathrm{Zn})$ is an important trace element for the maintenance of body normal physiological functions [1]. Zn is ubiquitously distributed in animal bones, muscles, liver, kidney and skin. It regulates the activities of multiple biological molecules such as transcription factors, enzymes, growth factors, etc [2]. Zn deficiency can cause retarded growth in pigs [3] and depressed immune responses [4] and parakeratosis [5]. Nowadays, feeding supplemental $\mathrm{Zn}$ to pigs is a common application in the pig industry to improve feed intake and immune function and to decrease gastro-intestinal stress after weaning, which in turn effectively enhances the growth performance in pigs [6,7].

On the other hand, widely supplementing $\mathrm{Zn}$ in pig feed raises a potential concern regarding environmental pollution. According to the 2012 National Research Council (NRC) 
[8] recommendations, the feed addition of $\mathrm{Zn}$ is $100 \mathrm{mg} / \mathrm{kg}$ for weanling piglets weighing 7 to $11 \mathrm{~kg}$; and is $80 \mathrm{mg} / \mathrm{kg}$ for those weighing 11 to $25 \mathrm{~kg}$. In 2014, European Food Safety Authority (EFSA) proposed $150 \mathrm{mg} \mathrm{Zn/kg} \mathrm{in} \mathrm{complete} \mathrm{feed}$ for pigs [9]. In 2017, the European Medicines Agency (EMA) recommended the future limit on $\mathrm{Zn}$ oxide in pig feeds. They claimed that the environmental risks arising from dietary $\mathrm{Zn}$ oxide addition are greater than the gain from the prevention of piglet diarrhea [10]. In China, Ministry of Agriculture (MOA) has reduced the lower limit of supplemental $\mathrm{Zn}$ from $70 \mathrm{mg} / \mathrm{kg}$ in 2007 to $40 \mathrm{mg} / \mathrm{kg}$ in 2009 [11]. Animal scientists are devoted to seek solutions to restrict the supplemental dose of $\mathrm{Zn}$ and improve its utilization in animals.

Organic $\mathrm{Zn}$ is a group of $\mathrm{Zn}$ chelates in which the ligands donate free electron pairs to $\mathrm{Zn}$ [12]. Reported organic $\mathrm{Zn}$ includes $\mathrm{Zn}$ chelates with amino acids, protein and carbohydrates. Multiple factors can affect the absorption and utilization of $\mathrm{Zn}$ in the body, such as chelation strengths, mineral interaction and diet compositions [13]. Amino acids are frequently used as dietary ligands for synthesis of $\mathrm{Zn}$ chelates. Organic $\mathrm{Zn}$ sources are absorbed via peptide or amino acid transport systems resulting in improved digestibility and availability of $\mathrm{Zn}$. Organic $\mathrm{Zn}$ has been shown to enhance $\mathrm{Zn}$ retention by reducing urinary $\mathrm{Zn}$ excretion compared with inorganic $\mathrm{Zn}$, whereas there was no differences in apparent $\mathrm{Zn}$ absorption [14]. The bioavailability of zinc from $\mathrm{Zn}$-methionine was significantly better than a double dose of zinc from $\mathrm{Zn}$ sulfate [15].

Zinc secretion from the supplemented animals have raised concerns on environmental pollution [16]. The reported ranges of organic $\mathrm{Zn}$ in feed supplements are mostly over $80 \mathrm{mg} / \mathrm{kg}$ $\mathrm{Zn}$ [17-19] in weanling pigs. A much lower dose was reported in growing pigs [20]. We hypothesized that a lower dose of organic $\mathrm{Zn}$ in weanling pig diets could be used without negatively impacting growth performance. The objectives of this study were to investigate the effects of supplemental levels of zinc amino acid complex (ZnAA) on the growth performance, blood hematological and biochemical parameters in weanling pigs, in order to provide the fundamental data for its efficiency and safety in the application in pig feeds.

\section{MATERIALS AND METHODS}

\section{Materials}

The ZnAA (containing 17\% of zinc) used in the current experiment was a 1:1 complex of zinc lysine and zinc glutamic acid (Zinpro Zn170) which was provided by Zinpro Corporation (Edina, MN, USA).

\section{Animals and experimental design}

All animal procedures and animal care were approved by the Institutional Animal Care and Use Committee of China Agri- cultural University (Beijing, China).

The experiments were conducted in the Pig Research Facility at the Swine Nutrition Research Centre of National Feed Engineering Technology Research Centre (Chengde, Hebei, China). One nursery barn was used in the study. The barn was a closed facility with mechanical ventilation equipment, equipped with 36 pens and 6 pigs (three barrows and three gilts) per pen resulting in $0.45 \mathrm{~m}^{2}$ per pig $(1.8 \mathrm{~m} \times 1.5 \mathrm{~m} / 6)$. The floor was one-half slatted concrete floor. Each pen was equipped with 1 nipple waterer and 1 feeder.

\section{Experiment 1}

A total of 216 crossbred pigs (Duroc $\times$ Landrace $\times$ Yorkshire) with an average initial body weight (BW) of $8.47 \pm 1.40 \mathrm{~kg}$ were blocked according to gender, ancestry and BW. Pigs were allotted to one of six dietary treatments with six replicate pens in each treatment. The six groups were as follows: i) control (basal diet no $\mathrm{Zn}$ supplementation) $+40 \mathrm{mg} \mathrm{Zn/kg} \mathrm{from} \mathrm{zinc}$ sulfate. ii) control; iii) control $+20 \mathrm{mg} \mathrm{Zn} / \mathrm{kg}$ from $\mathrm{ZnAA}$; iv) control+40 mg Zn/kg from ZnAA; v) control+80 mg Zn/kg from $\mathrm{ZnAA}$; vi) control+120 mg Zn/kg from $\mathrm{ZnAA}$; The basal diet, comprised of corn, soybean meal, soy protein concentrate and dried whey, was formulated to meet or exceed NRC [8] requirements for weanling piglets except for $\mathrm{Zn}$ (Table 1) in a 2-phase feeding program. Analyzed $\mathrm{Zn}$ concentrations in diets are listed in Table 2. The experiment lasted 42 days and was divided into an early (d 0 to 14 ) and late phase (d 15 to 42 ). Pigs had ad libitum to access to feed and water.

Each piglet was weighed on d 0, 14 and 42. Feed consumption was recorded daily to calculate the average daily gain (ADG), average daily feed intake (ADFI) and feed to gain ratio (F:G). ADG, ADF, and F/G were calculated as: $A D G=$ total weight gain/days of experiment; ADFI = total feed consumption/days of experiment; F/G = ADFI/ADG. Pig fecal consistency was observed and scored from $\mathrm{d} 0$ following the standards of diarrhea scoring. The feces were scored twice a day at 8:00 am and 3:00 pm. The highest score of the pig on each day was used to calculate the diarrhea index. The calculation formula was: Diarrhea rate $=[$ total number of diarrhea pigs/(total number of pigs $\times$ days of experiment) $] \times 100 \%$; Diarrhea index $=$ sum of all fecal scores from all piglets during the experiment/(days of experiment $\times$ numbers of pigs). Fecal score falling into 2 and 3 on the same day was deemed as diarrhea on that day.

On $\mathrm{d} 0$ and 42, one barrow and one gilt were selected randomly from each pen for blood sampling. Blood was collected from the anterior vena cava using anticoagulant-free tubes followed by centrifugation at $1,500 \mathrm{~g}$ for $10 \mathrm{~min}$ at $4^{\circ} \mathrm{C}$. The sera were stored at $-20^{\circ} \mathrm{C}$ for further analysis.

\section{Experiment 2}

In China, the Ministry of Agriculture has a mandatory require- 
Table 1. Composition and chemical composition of the basal diets (as-fed basis)

\begin{tabular}{lcc}
\hline Items & Phase 1 & Phase 2 \\
\hline Ingredient (\%) & & \\
Maize & 58.47 & 59.51 \\
Soybean meal & 16.50 & 20.00 \\
Soybean oil & 3.00 & 2.72 \\
Soybean protein concentrate & 9.07 & 3.47 \\
Fish meal & 2.00 & 2.30 \\
Dried whey & 6.99 & 8.50 \\
Dicalcium phosphate & 1.32 & 1.04 \\
Limestone & 0.75 & 0.61 \\
Salt & 0.20 & 0.25 \\
L-lysine-HCl & 0.52 & 0.49 \\
L-threonine & 0.17 & 0.15 \\
L-tryptophan & 0.02 & 0.02 \\
Methionine hydroxy analogue & 0.29 & 0.24 \\
Choline chloride & 0.20 & 0.20 \\
Vitamin-mineral premix) & 0.50 & 0.50 \\
Total & 100.00 & 100.00 \\
Nutrient levels & & \\
Digestible energy (MJ/kg) & 14.82 & 14.61 \\
Crude protein & 20.56 & 18.87 \\
Lysine & 1.53 & 1.40 \\
Methionine & 0.57 & 0.50 \\
Methionine+cysteine & 0.87 & 0.79 \\
Threonine & 0.95 & 0.87 \\
Calcium & 0.80 & 0.70 \\
Total phosphorus & 0.65 & 0.60 \\
\hline
\end{tabular}

1) Premix provided per kg of diet: early phase: Vitamin $A_{1}, 12$ KIU; Vitamin $D_{3}, 2$ KIU; Vitamin E, 30.0 IU; Vitamin $\mathrm{K}_{3}, 2.50$ mg; Vitamin $\mathrm{B}_{1}, 2.50$ mg; Vitamin $\mathrm{B}_{2}, 4.00$ $\mathrm{mg}$; Vitamin $\mathrm{B}_{6}, 7.0 \mathrm{mg}$; Vitamin $\mathrm{B}_{12}, 20.0 \mu \mathrm{g}$; Nicotinic acid, $40.0 \mathrm{mg}$; Pantothenic acid, $12.5 \mathrm{mg}$; Folic acid, $0.7 \mathrm{mg}$; Biotin, $80 \mu \mathrm{g} ; \mathrm{Fe}, 100 \mathrm{mg}$; Cu, 90 mg; Mn, 30 $\mathrm{mg} ; \mathrm{I}, 0.25 \mathrm{mg} ; \mathrm{Se}, 0.3 \mathrm{mg}$. Zinc was not be supplied in the premix. Late phase: $\mathrm{Vi}-$ tamin A, 6 KIU; Vitamin D, 2 KIU; Vitamin E, 25.0 IU; Vitamin K $2,2.0$ mg; Vitamin $B_{1}, 2.0$ mg; Vitamin $B_{2}, 4.0$ mg; Vitamin $B_{6}, 7.0$ mg; Vitamin $B_{12}, 20.0 \mu$; Nicotinic acid, $40.0 \mathrm{mg}$; Pantothenic acid, $12.5 \mathrm{mg}$; Folic acid, $0.7 \mathrm{mg}$; Biotin, $80 \mu \mathrm{g}$; Fe, 100 mg; Cu, 90 mg; Mn, 20 mg; I, 0.25 mg; Se, 0.3 mg. Zinc was not supplied in the premix.

ment for inclusion of hematological evaluation for all new feedstuffs or feed additives [21]. It is believed this requirement is in place because hematological parameters are closely associated with systemic metabolic status. We thus performed hematological test of pig plasma to demonstrate the healthy status of the pigs. According to the Guideline [21], ten times the effective dose should be selected to evaluate the additive's safety in animals. We had found three doses (20,40, and 80 $\mathrm{mg} / \mathrm{kg} \mathrm{ZnAA}$ ) effective in ADG and F:G in Phase I and the entire phase in Exp 1, compared to the unsupplemented group. Therefore the high dose of $80 \mathrm{mg} / \mathrm{kg}$ and its ten-time group $800 \mathrm{mg} / \mathrm{kg}$ were selected for Exp 2. A total of 108 Durocx Landrace $\times$ Yorkshire crossbred weanling pigs $(9.16 \pm 1.04 \mathrm{~kg})$ were blocked into three groups based on gender, ancestry and BW with six replicates in each treatment and six pigs (three barrows and three gilts) per pen. Pigs had ad libitum access
Table 2. Analyzed Zn concentration in diets for pigs

\begin{tabular}{|c|c|c|c|c|}
\hline & \multirow[t]{2}{*}{ Zn source } & \multirow[t]{2}{*}{ Added Zn (mg/kg) } & \multicolumn{2}{|c|}{ Dietary $\mathrm{Zn}^{1)}(\mathrm{mg} / \mathrm{kg})$} \\
\hline & & & d 0 to $d 14$ & d 15 to $d 42$ \\
\hline \multirow[t]{7}{*}{ Exp. 1} & Zn sulfate & 40 & 86.7 & 83.7 \\
\hline & ZnAA & 0 & 44.3 & 38.2 \\
\hline & & 20 & 68.0 & 57.1 \\
\hline & & 40 & 86.6 & 82.8 \\
\hline & & 80 & 125.3 & 113.1 \\
\hline & & 120 & 177.3 & 160.3 \\
\hline & & & d 0 to $d 14$ & d 15 to $d 28$ \\
\hline \multirow[t]{3}{*}{ Exp. 2} & ZnAA & 0 & 46.0 & 42.5 \\
\hline & & 80 & 128.3 & 126.4 \\
\hline & & 800 & 812.4 & 830.9 \\
\hline
\end{tabular}

ZnAA, zinc amino acid complex.

1) Values based on chemical analysis of triplicate samples of diets. Values for $\mathrm{Zn}$ concentrations are reported on an as-fed basis.

to feed and water. Pigs were fed with a basal diet as in Exp 1 supplemented with 0,80 , or $800 \mathrm{mg} \mathrm{Zn} / \mathrm{kg}$ from ZnAA for 28 days. A 2-phase feeding program was applied: $\mathrm{d}$ 0-14 and $\mathrm{d}$ $15-28$ postweaning. On $\mathrm{d} 0,14$, and 28 , one pig from each pen (total three barrows and three gilts for each treatment) was selected for blood sampling from the anterior vena cava using ethylenediaminetetraacetic acid dipotassium salt-containing and anticoagulant-free tubes for preparation of plasma and serum, respectively. Hematological parameters were assayed within $1 \mathrm{~h}$ after sampling. The sera were stored at $-20^{\circ} \mathrm{C}$ for further analysis.

\section{Chemical analysis}

The activities of serum alkaline phosphatase (ALP) and $\mathrm{Cu}-\mathrm{Zn}$ Superoxide Dismutase (CuZn-SOD) were measured using commercially available kits according to manusfacturers instructions (ALP, BioSino Biotechnology and Science Company, Beijing, China) and an automatic biochemical analyzer (Hitachi 7160, Hitachi Group, Tokyo, Japan). Superoxide dismutase (SOD) activity was measured using the SOD assay kit (Nanjing Jiancheng Bioengineering Institute, Nanjing, China), based on the xanthinexanthine oxidase system. After total SOD (CuZnSOD and Mn SOD) was determined, samples were again analyzed in the presence of $500 \mathrm{M} \mathrm{KCN}$ to inhibit CuZn SOD and to obtain Mn SOD activity. CuZn-SOD activity was obtained by subtracting Mn SOD activity. Feed and serum $\mathrm{Zn}$ levels were determined with ICP-MS (Agilent 7500, Agilent Technologies, Inc., USA).

\section{Analysis of hematological and serum biochemical parameters}

Hematological parameters, including white blood cells, red blood cells, hemoglobin, hematocrit, and platelet count were determined using a Sysmex Microcell Counter CL-180 (Tokyo, Japan). Serum biochemical parameters were determined us- 
ing corresponding commercially available kits (BioSino Biotechnology and Science Company, Beijing, China), which included glucose, ALP, total protein, albumin, aspartate aminotransferase (AST), alanine aminotransferase (ALT), cholesterol, triglyceride, creatinine, and urea nitrogen. Analyses were conducted on an automatic biochemical analyzer (Hitachi 7160, Hitachi Group, Japan).

\section{Statistical analysis}

Data were analyzed using one-way analysis of variance in accordance with the general linear model procedures of SAS 9.2 (SAS Institute Inc., Cary, NC, USA) as a randomized complete block design including the terms for treatments and block (weight). Each pen was deemed as one experimental unit for growth performance, while an individual pig was considered as the experimental unit for other indices. Interactive matrix algebra procedure (IML) of SAS was adopted to generate the coefficients of unequally spaced contrasts. Subsequently, the linear and quadratic responses of $\mathrm{Zn}$ level of $\mathrm{ZnAA}$ were assessed by the orthogonal polynomial contrast. Significance level was set at $\mathrm{p}<0.05$.

\section{RESULTS}

\section{Experiment 1}

Growth performance: The growth performance of the weanling pigs is presented in Table 3 . In the early phase ( $\mathrm{d} 0$ to 14 ), ADG was higher $(\mathrm{p}<0.05)$ for pigs fed diets supplemented with 20, 40, and $80 \mathrm{mg} \mathrm{Zn} / \mathrm{kg}$ from $\mathrm{ZnAA}$ compared to pigs fed the unsupplemented diet. Further, there was a quadratic re- sponse $(\mathrm{p}<0.05)$ in ADG and F:G to increasing ZnAA. During d 15 to $d 42$, the pigs fed supplemental $\mathrm{Zn}$ from ZnAA had lower F:G (linear and quadratic, $p<0.05$ ). The overall ADG was significantly lower in weanling pigs fed the control diet, as compared to the supplemented groups $(\mathrm{p}<0.05)$. The $\mathrm{F}: \mathrm{G}$ was lower $(\mathrm{p}<0.05)$ for pigs fed diets supplemented with 20 , 40 , 80, and $120 \mathrm{mg} \mathrm{Zn} / \mathrm{kg}$ from ZnAA compared to pigs fed the unsupplemented diet. There were linear and quadratic responses $(\mathrm{p}<0.05)$ in $\mathrm{F}: \mathrm{G}$ of $\mathrm{ZnAA}$ supplemented pigs to increasing ZnAA.

The diarrhea rate and diarrhea index: The effects of graded levels of ZnAA on the diarrhea rate and diarrhea index of weanling pigs were not different among the pigs fed 0 to 120 $\mathrm{mg} \mathrm{Zn} / \mathrm{kg}$ from $\mathrm{ZnAA}$ or the zinc sulfate group in the early phase ( 0 to $\mathrm{d} 14$ ), late phase ( 15 to $\mathrm{d} 42$ ) and the entire phase ( 0 to $d 42)(p>0.05)$ (data not shown).

Specific indicators: We measured the serum specific indicators including the activities of CuZn-SOD, ALP, and Zn levels (Table 4). On d 14, ALP was lower in the unsupplemented group compared to 80 and $120 \mathrm{ZnAA}$. Serum $\mathrm{Zn}$ was lower in the unsupplemented group compared to 20,40,80, and $120 \mathrm{mg} / \mathrm{kg} \mathrm{ZnAA}$ as well as $\mathrm{ZnSO}_{4}$. serum CuZn-SOD activity was greater $(\mathrm{p}<0.05)$ in pigs fed $\mathrm{Zn}$ from $\mathrm{ZnAA}$ compared to pigs fed the unsupplemented diet. On $\mathrm{d} 42$, the activity of serum ALP and Zn levels showed differences between treatments. There was a linear increase in serum ALP and $\mathrm{Zn}$ with increasing $\mathrm{ZnAA}(\mathrm{p}<0.05)$ and a quadratic increase in serum CuZn-SOD with increasing ZnAA ( $\mathrm{p}<0.05)$.

\section{Experiment 2}

Table 3. Effects of zinc sulfate and zinc amino acid complex (ZnAA) on growth performance in weanling pigs ${ }^{11}(\mathrm{Zn}, \mathrm{mg} / \mathrm{kg})$

\begin{tabular}{|c|c|c|c|c|c|c|c|c|c|c|}
\hline \multirow{2}{*}{ Items } & \multirow{2}{*}{$\begin{array}{c}\mathrm{ZnSO}_{4} \\
40\end{array}$} & \multicolumn{5}{|c|}{ ZnAA } & \multirow{2}{*}{ SEM } & \multicolumn{3}{|c|}{ p-value } \\
\hline & & 0 & 20 & 40 & 80 & 120 & & ANOVA & Linear $^{2)}$ & Quadratic ${ }^{2)}$ \\
\hline \multicolumn{11}{|l|}{ Early phase, d 0 to 14} \\
\hline ADG $(g)$ & $231^{\mathrm{ab}}$ & $201^{\mathrm{a}}$ & $237^{b}$ & $249^{b}$ & $255^{b}$ & $227^{\mathrm{ab}}$ & 12 & 0.049 & 0.221 & 0.007 \\
\hline ADFI (g) & 404 & 395 & 408 & 396 & 390 & 403 & 22 & 0.993 & 0.976 & 0.822 \\
\hline$F: G$ & 1.75 & 1.97 & 1.73 & 1.62 & 1.58 & 1.78 & 0.11 & 0.223 & 0.308 & 0.028 \\
\hline Mortality rate (\%) & 2.78 & 2.78 & 2.78 & 0.00 & 2.78 & 2.78 & 2.54 & 0.960 & 0.898 & 0.631 \\
\hline \multicolumn{11}{|l|}{ Late phase, d 15 to 42} \\
\hline ADG $(g)$ & 542 & 518 & 557 & 546 & 552 & 548 & 13 & 0.420 & 0.309 & 0.223 \\
\hline ADFI (g) & 772 & 852 & 825 & 770 & 766 & 778 & 33 & 0.338 & 0.085 & 0.165 \\
\hline$F: G$ & 1.43 & 1.65 & 1.48 & 1.43 & 1.39 & 1.43 & 0.06 & 0.090 & 0.021 & 0.037 \\
\hline Mortality rate (\%) & 0.00 & 0.00 & 0.00 & 0.00 & 0.00 & 0.00 & - & - & - & - \\
\hline \multicolumn{11}{|c|}{ Entire experiment, d 0 to 42} \\
\hline ADG $(\mathrm{g})$ & $438^{\mathrm{ab}}$ & $413^{\mathrm{a}}$ & $450^{b}$ & $447^{b}$ & $453^{b}$ & $441^{b}$ & 9 & 0.046 & 0.128 & 0.019 \\
\hline ADFI (g) & 649 & 700 & 686 & 645 & 641 & 653 & 24 & 0.417 & 0.104 & 0.170 \\
\hline $\mathrm{F}: \mathrm{G}$ & $1.49^{\mathrm{ab}}$ & $1.70^{\mathrm{a}}$ & $1.52^{b}$ & $1.45^{b}$ & $1.42^{b}$ & $1.48^{b}$ & 0.06 & 0.026 & 0.011 & 0.006 \\
\hline Mortality rate (\%) & 2.78 & 2.78 & 2.78 & 0.00 & 2.78 & 2.78 & 2.54 & 0.960 & 0.898 & 0.631 \\
\hline
\end{tabular}

SEM, standard error of the mean; ANOVA, analysis of variance; $A D G$, average daily gain; $A D F I$, average daily feed intake; $F: G$, feed to gain ratio.

1) Data are the means of six replicates of six pigs (three barrows and three gilts) per pen.

2) Linear and quadratic analysis of increasing ZnAA (0 to $120 \mathrm{mg}$ Zn from ZnAA).

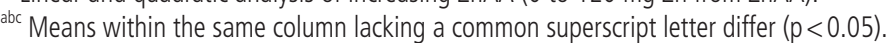


Table 4. Effects of zinc sulfate and zinc amino acid complex (ZnAA) on serum Zn levels, activities of ALP and CuZn-SOD in weanling pigs") (Zn, mg/kg)

\begin{tabular}{|c|c|c|c|c|c|c|c|c|c|c|}
\hline \multirow{2}{*}{ Items } & \multirow{2}{*}{$\begin{array}{c}\mathrm{ZnSO}_{4} \\
40\end{array}$} & \multicolumn{5}{|c|}{ ZnAA } & \multirow{2}{*}{ SEM } & \multicolumn{3}{|c|}{$\mathrm{p}$-value } \\
\hline & & 0 & 20 & 40 & 80 & 120 & & ANOVA & Linear $^{2)}$ & Quadratic \\
\hline \multicolumn{11}{|l|}{$0 \mathrm{~d}$} \\
\hline $\operatorname{ALP}(\mathrm{U} / \mathrm{L})$ & 317.45 & 369.29 & 346.71 & 333.37 & 297.51 & 330.20 & 36.48 & 0.807 & 0.342 & 0.372 \\
\hline $\operatorname{Zn}(\mu \mathrm{mol} / \mathrm{L})$ & 16.01 & 17.58 & 16.08 & 16.27 & 15.75 & 15.03 & 1.62 & 0.928 & 0.325 & 0.827 \\
\hline CuZn-SOD (U/mL) & 41.35 & 43.89 & 44.46 & 44.79 & 41.35 & 40.26 & 4.05 & 0.948 & 0.396 & 0.806 \\
\hline \multicolumn{11}{|l|}{$14 \mathrm{~d}$} \\
\hline $\operatorname{ALP}(U / L)$ & 209.94 & 185.66 & 196.73 & 263.83 & 260.82 & 210.06 & 29.61 & 0.314 & 0.440 & 0.072 \\
\hline $\mathrm{Zn}(\mu \mathrm{mol} / \mathrm{L})$ & 11.78 & 10.91 & 9.76 & 12.66 & 14.08 & 12.96 & 1.28 & 0.237 & 0.058 & 0.335 \\
\hline CuZn-SOD (U/mL) & $54.00^{\mathrm{ab}}$ & $45.01^{\mathrm{a}}$ & $52.81^{b}$ & $57.70^{\mathrm{b}}$ & $62.85^{b}$ & $58.54^{b}$ & 3.39 & 0.021 & 0.008 & 0.027 \\
\hline \multicolumn{11}{|l|}{$42 \mathrm{~d}$} \\
\hline $\operatorname{ALP}(U / L)$ & $185.90^{a b}$ & $143.83^{\mathrm{a}}$ & $173.14^{\mathrm{ab}}$ & $183.38^{\text {ab }}$ & $206.37^{b}$ & $209.16^{b}$ & 15.07 & 0.050 & 0.003 & 0.207 \\
\hline $\mathrm{Zn}(\mu \mathrm{mol} / \mathrm{L})$ & $11.19^{b}$ & $8.31^{\mathrm{a}}$ & $9.63^{\mathrm{a}}$ & $11.05^{b}$ & $12.32^{b}$ & $12.13^{b}$ & 0.86 & 0.022 & 0.001 & 0.088 \\
\hline CuZn-SOD (U/mL) & 59.86 & 54.98 & 60.30 & 68.31 & 67.54 & 60.89 & 4.47 & 0.301 & 0.291 & 0.025 \\
\hline
\end{tabular}

ALP, alkaline phosphatase; CuZn-SOD, Cu-Zn superoxide dismutase; SEM, standard error of the mean; ANOVA, analysis of variance; ALP, alkaline phosphatase.

1) Data are the means of six replicates of one pig per pen.

2) Linear analysis of increasing ZnAA (0 to $120 \mathrm{mg}$ Zn from ZnAA).

abc Means within the same column lacking a common superscript letter differ $(p<0.05)$.

Growth performance: In Exp. 2, we selected two doses of Zn from $\mathrm{ZnAA}, 80$ and $800 \mathrm{mg} \mathrm{Zn/kg}$ to evaluate the safety of ZnAA in weaned pigs (Table 5). For the growth performance, in the later phase (d 15 to $\mathrm{d} 28$ ), pigs fed ZnAA had higher $\mathrm{ADFI}(\mathrm{p}<0.05)$ compared to the unsupplemented group. In the entire phase ( $\mathrm{d} 0$ to $\mathrm{d} 28$ ), ADG was higher for pigs fed 80 or $800 \mathrm{mg} \mathrm{Zn/kg}$ from ZnAA than the unsupplemented group $(\mathrm{p}<0.05)$. The supplemented groups tended to show lower F:G

Table 5. Effects of zinc amino acid complex (ZnAA) on growth performance in weaned pigs ${ }^{1)}(\mathrm{Zn}, \mathrm{mg} / \mathrm{kg})$

\begin{tabular}{|c|c|c|c|c|c|}
\hline \multirow{2}{*}{ Items } & \multicolumn{3}{|c|}{$\mathrm{ZnAA}$} & \multirow{2}{*}{ SEM } & \multirow{2}{*}{$\frac{p \text {-value }}{\text { ANOVA }}$} \\
\hline & 0 & 80 & 800 & & \\
\hline \multicolumn{6}{|l|}{ Phase I, 0 to $14 \mathrm{~d}$} \\
\hline ADG $(g)$ & 259 & 282 & 268 & 14 & 0.501 \\
\hline ADFI (g) & 427 & 416 & 420 & 16 & 0.875 \\
\hline $\mathrm{F}: \mathrm{G}$ & 1.68 & 1.47 & 1.59 & 0.10 & 0.386 \\
\hline Mortality rate (\%) & 0.00 & 0.00 & 2.78 & 1.60 & 0.391 \\
\hline \multicolumn{6}{|l|}{ Phase II, 15 to $42 \mathrm{~d}$} \\
\hline ADG $(g)$ & 329 & 393 & 400 & 22 & 0.091 \\
\hline ADFI (g) & $594^{\mathrm{a}}$ & $632^{b}$ & $665^{b}$ & 15 & 0.021 \\
\hline $\mathrm{F}: \mathrm{G}$ & 1.82 & 1.65 & 1.69 & 0.11 & 0.516 \\
\hline Mortality rate (\%) & 0.00 & 0.00 & 0.00 & - & - \\
\hline \multicolumn{6}{|c|}{ Entire experiment, 0 to $42 \mathrm{~d}$} \\
\hline ADG (g) & $294^{\mathrm{a}}$ & $338^{b}$ & $334^{b}$ & 11 & 0.040 \\
\hline ADFI (g) & 511 & 524 & 543 & 11 & 0.149 \\
\hline $\mathrm{F}: \mathrm{G}$ & 1.74 & 1.56 & 1.64 & 0.05 & 0.079 \\
\hline Mortality rate (\%) & 0.00 & 0.00 & 2.78 & 1.60 & 0.391 \\
\hline \multicolumn{6}{|c|}{$\begin{array}{l}\text { SEM, standard error of the mean; ANOVA, analysis of variance; ADG, average daily } \\
\text { gain; } A D F I \text {, average daily feed intake; F:G, feed to gain ratio. } \\
\text { 1) Data are the means of six replicates of six pigs (three barrows and three gilts) } \\
\text { per pen. } \\
\text { abc Means within the same column lacking a common superscript letter differ } \\
(p<0.05) \text {. }\end{array}$} \\
\hline
\end{tabular}

compared to the unsupplemented control $(\mathrm{p}=0.05)$.

Hematological parameters: The effects of different dietary supplementation levels of $\mathrm{Zn}$ from $\mathrm{ZnAA}$ on the hematological parameters of weaned piglets are presented in Table 6. No significant differences were found in the hematological parameters among the pigs fed 80 or $800 \mathrm{mgZn} / \mathrm{kg}$ as $\mathrm{ZnAA}$ and the pigs fed the unsupplemented $\operatorname{diet}(\mathrm{p}>0.05)$.

Table 6. Effects of zinc amino acid complex (ZnAA) on hematological parameters in weaned pigs ${ }^{1)}(\mathrm{Zn}, \mathrm{mg} / \mathrm{kg})$

\begin{tabular}{|c|c|c|c|c|c|}
\hline \multirow{2}{*}{ Items } & \multicolumn{3}{|c|}{ ZnAA } & \multirow{2}{*}{ SEM } & \multirow{2}{*}{$\begin{array}{l}\mathrm{p} \text {-value } \\
\text { ANOVA }\end{array}$} \\
\hline & 0 & 80 & 800 & & \\
\hline \multicolumn{6}{|l|}{$0 d$} \\
\hline WBC $\left(10^{9} / \mathrm{L}\right)$ & 17.25 & 16.67 & 16.32 & 1.43 & 0.899 \\
\hline $\operatorname{RBC}\left(10^{12} / L\right)$ & 5.74 & 6.03 & 5.66 & 0.24 & 0.533 \\
\hline HGB (g/L) & 100.00 & 100.17 & 94.83 & 3.91 & 0.566 \\
\hline $\mathrm{HCT}(\%)$ & 0.32 & 0.32 & 0.29 & 0.01 & 0.150 \\
\hline $\operatorname{PLT}\left(10^{9} / \mathrm{L}\right)$ & 379.33 & 449.83 & 406.33 & 34.66 & 0.385 \\
\hline \multicolumn{6}{|l|}{$14 d$} \\
\hline WBC $\left(10^{9} / \mathrm{L}\right)$ & 19.22 & 18.33 & 20.27 & 1.42 & 0.640 \\
\hline $\mathrm{RBC}\left(10^{12} / \mathrm{L}\right)$ & 6.28 & 6.71 & 6.81 & 0.28 & 0.416 \\
\hline$H G B(g / L)$ & 106.83 & 105.17 & 102.17 & 4.34 & 0.750 \\
\hline $\mathrm{HCT}(\%)$ & 0.39 & 0.39 & 0.38 & 0.02 & 0.940 \\
\hline PLT $\left(10^{9} / \mathrm{L}\right)$ & 315.83 & 303.17 & 307.33 & 35.41 & 0.967 \\
\hline \multicolumn{6}{|l|}{$28 \mathrm{~d}$} \\
\hline WBC $\left(10^{9} / L\right)$ & 19.32 & 21.82 & 21.07 & 1.40 & 0.461 \\
\hline $\operatorname{RBC}\left(10^{12} / L\right)$ & 6.41 & 6.61 & 6.82 & 0.21 & 0.406 \\
\hline HGB (g/L) & 113.17 & 108.83 & 112.00 & 3.00 & 0.588 \\
\hline HCT $(\%)$ & 0.35 & 0.34 & 0.35 & 0.01 & 0.911 \\
\hline PLT $\left(10^{9} / \mathrm{L}\right)$ & 358.00 & 359.83 & 407.17 & 37.18 & 0.587 \\
\hline
\end{tabular}

SEM, standard error of the mean; ANOVA, analysis of variance; WBC, white blood cells; RBC, red blood cells; HGB, hemoglobin; HCT, hematocrit; PLT, platelet count.

${ }^{1)}$ Data are the means of six replicates of one pig per pen. 
Serum biochemical parameters: The effects of different dietary supplementation levels of $\mathrm{Zn}$ from $\mathrm{ZnAA}$ on the serum biochemical parameters of weaned piglets are presented in Table 7. The activities of serum ALP in the pigs fed 80 and $800 \mathrm{mg} \mathrm{Zn} / \mathrm{kg}$ from ZnAA were higher than that of the pigs fed the unsupplemented diet at $\mathrm{d} 14$ and $\mathrm{d} 28(\mathrm{p}<0.05)$.

\section{DISCUSSION}

Absorption of minerals is a major factor limiting their use for biological funcitons within the body. A trace mineral can be absorbed but is not necessarily utilized. Inorganic sourced mineral ions are easily combined with other components in

Table 7. Effects of zinc amino acid complex (ZnAA) on serum biochemical parameters in weaned pigs ${ }^{1)}(\mathrm{Zn}, \mathrm{mg} / \mathrm{kg})$

\begin{tabular}{|c|c|c|c|c|c|}
\hline \multirow{2}{*}{ Items } & \multicolumn{3}{|c|}{ ZnAA } & \multirow{2}{*}{ SEM } & \multirow{2}{*}{$\begin{array}{l}p \text { value } \\
\text { ANOVA }\end{array}$} \\
\hline & 0 & 80 & 800 & & \\
\hline \multicolumn{6}{|l|}{$0 \mathrm{~d}$} \\
\hline TBILI ( $\mu \mathrm{mol} / \mathrm{L})$ & 2.60 & 2.05 & 2.55 & 00.51 & 0.707 \\
\hline CRE $(\mu \mathrm{mol} / \mathrm{L})$ & 95.17 & 94.55 & 81.58 & 06.49 & 0.292 \\
\hline UN (mmol/L) & 2.64 & 2.82 & 2.92 & 00.28 & 0.785 \\
\hline $\operatorname{ALP}(U / L)$ & 338.40 & 351.13 & 346.23 & 24.35 & 0.933 \\
\hline ALT (U/L) & 33.00 & 32.87 & 33.90 & 03.94 & 0.980 \\
\hline AST (U/L) & 59.92 & 61.20 & 57.25 & 06.57 & 0.911 \\
\hline $\mathrm{TP}(\mathrm{g} / \mathrm{L})$ & 38.67 & 43.72 & 40.55 & 04.07 & 0.684 \\
\hline $\mathrm{ALB}(\mathrm{g} / \mathrm{L})$ & 29.00 & 30.27 & 27.98 & 02.01 & 0.730 \\
\hline GLU (mmol/L) & 2.77 & 2.80 & 2.70 & 00.45 & 0.986 \\
\hline \multicolumn{6}{|l|}{$14 \mathrm{~d}$} \\
\hline TBILI $(\mu \mathrm{mol} / \mathrm{L})$ & 3.12 & 3.42 & 3.20 & 00.39 & 0.855 \\
\hline CRE $(\mu \mathrm{mol} / \mathrm{L})$ & 105.33 & 100.92 & 107.90 & 06.93 & 0.776 \\
\hline UN (mmol/L) & 3.69 & 3.26 & 3.08 & 00.21 & 0.168 \\
\hline $\operatorname{ALP}(U / L)$ & $214.43^{\mathrm{a}}$ & $279.37^{b}$ & $270.80^{b}$ & 16.41 & 0.038 \\
\hline ALT (U/L) & 36.02 & 39.12 & 40.97 & 03.37 & 0.593 \\
\hline AST (U/L) & 55.10 & 55.95 & 58.22 & 04.01 & 0.853 \\
\hline $\mathrm{TP}(\mathrm{g} / \mathrm{L})$ & 47.88 & 46.65 & 46.92 & 03.41 & 0.965 \\
\hline $\mathrm{ALB}(\mathrm{g} / \mathrm{L})$ & 31.52 & 29.28 & 28.27 & 02.18 & 0.577 \\
\hline GLU (mmol/L) & 4.29 & 3.96 & 4.31 & 00.54 & 0.875 \\
\hline \multicolumn{6}{|l|}{$28 d$} \\
\hline TBILI ( $\mu \mathrm{mol} / \mathrm{L})$ & 4.17 & 4.25 & 3.97 & 00.34 & 0.837 \\
\hline CRE $(\mu \mathrm{mol} / \mathrm{L})$ & 112.57 & 103.07 & 104.43 & 06.91 & 0.592 \\
\hline UN (mmol/L) & 3.67 & 3.10 & 3.25 & 00.30 & 0.411 \\
\hline $\operatorname{ALP}(U / L)$ & $184.10^{a}$ & $230.53^{b}$ & $237.72^{b}$ & 11.55 & 0.017 \\
\hline ALT (U/L) & 41.72 & 48.78 & 48.68 & 02.33 & 0.093 \\
\hline AST (U/L) & 47.97 & 51.42 & 47.75 & 05.40 & 0.867 \\
\hline $\mathrm{TP}(\mathrm{g} / \mathrm{L})$ & 44.42 & 43.08 & 37.73 & 03.58 & 0.410 \\
\hline$A L B(g / L)$ & 27.48 & 24.00 & 22.55 & 01.70 & 0.160 \\
\hline $\mathrm{GLU}(\mathrm{mmol} / \mathrm{L})$ & 4.39 & 3.95 & 4.59 & 00.30 & 0.340 \\
\hline
\end{tabular}

SEM, standard error of the mean; ANOVA, analysis of variance; TBILI, total bilirubin; $C R E$, creatinine; UN, urea nitrogen; ALP, alkaline phosphatase; ALT, alanine aminotransferase; AST, aspartate aminotransferase; TP, total protein; ALB, albumin; GLU, glucose.

1) Data are the means of six replicates of one pig per pen.

abc Means within the same column lacking a common superscript letter differ $(p<0.05)$. digesta to form insoluble complexes, which reduce mineral absorption. Whereas, an organic trace mineral or chelated trace mineral, is in a chemically inert form via ligand binding and as such, is protected from negative interaction with the digesta components, such as phytate. Organic trace minerals use either amino acid or peptide uptake mechanisms for their absorption, thus they are expected to be absorbed and circulated to target tissues very efficiently. The effects of organic $\mathrm{Zn}$ on growth performance are conflicting [22-24]. Our study found that dietary supplementation of 20, 40, and $80 \mathrm{mg} \mathrm{Zn/kg}$ as $\mathrm{ZnAA}$ increased the $\mathrm{ADG}$ in weaned piglets compared to pigs fed an unsupplemented diet from $\mathrm{d} 0$ to $\mathrm{d} 14$ and $\mathrm{d} 0$ to $\mathrm{d} 42$. This response was similar to that of Zinc sulfate at $40 \mathrm{mg}$ $\mathrm{Zn} / \mathrm{kg}$.

Zinc sulfate and $\mathrm{Zn}$ oxide are commonly used as inorganic $\mathrm{Zn}$ controls in evaluation of organic Zn products. Pharmacological $\mathrm{Zn}$ oxide (3,000 to $5,000 \mathrm{mg} \mathrm{Zn} / \mathrm{kg}$ ) is effective in promoting growth and reducing diarrhea; however, due to the high $\mathrm{Zn}$ excretion and risk for environmental pollution, China MOA currently is considering reducing the allowable dose of $\mathrm{Zn}$ oxide in feeds [25]. Comparatively, Zinc sulfate is more efficiently utilized. Part of the reason is that sulfate, of several ligands tested, has been demonstarted to be the most effective in enhancing Zn uptake [26]. Lee reported that $120 \mathrm{mg}$ $\mathrm{Zn} / \mathrm{kg}$ from $\mathrm{Zn}$ methionine functioned similar to the same dose of Zinc sulfate [27]. Presently, most reports on the effective dose of organic $\mathrm{Zn}$ are over $80 \mathrm{mg} \mathrm{Zn/kg} \mathrm{[17-19].} \mathrm{In} \mathrm{this}$ study, we reported a lower effective dose of $\mathrm{ZnAA}$ from 20 to $80 \mathrm{mg} \mathrm{Zn/kg}$ for promoting growth performance. This indicates that a higher bioavailability can be achieved and explored for use of organic $\mathrm{Zn}$ which offers improved environmental protection.

Post weaning diarrhea is a serious common problem for pig production in the world. A large number of studies have been carried out on the dietary addition of high doses of $\mathrm{Zn}$ oxide to decrease post-weaning diarrhea $[22,28]$. In this study, the dose of $40 \mathrm{mg} / \mathrm{kg} \mathrm{Zn}$ as ZnAA did not show significantly lower mortality rates in the early phase ( $\mathrm{d} 0$ to $\mathrm{d} 14$ ) and the entire phase ( 0 to $\mathrm{d} 42)(\mathrm{p}=0.96)$ compared with other dietary treatments. Mortality rate was very low with limited development of severe diarrhea in any treatment group which may reflect a low level of weaning stress. Unfortunately, this limits the opportunity to infer beneficial impact of $\mathrm{ZnAA}$ on improving diarrhea incidence.

Alkaline phosphatase is an enzyme that catalyzes the release of inorganic phosphorus from phosphate monoester hydrolysis. Zinc is a necessary element for the synthesis of ALP, and body $\mathrm{Zn}$ level is positively correlated with the activity of this enzyme. A rat experiment showed that $\mathrm{Zn}$ level in the diet affected ALP activity [29]. In our study, serum ALP activity of weaned piglets tended to increase with increasing $\mathrm{ZnAA}$ dosage $(p=0.055)$, which demonstrates that serum ALP ac- 
tivity was positively correlated with systemic Zn levels. Our study also determined that systemic $\mathrm{Zn}$ levels were closely correlated with the dietary $\mathrm{Zn}$ levels, which is in agree with previous reports [30,31]. CuZn-SOD is a Zn-dependent enzyme which plays an important role in the antioxidant defense system to eliminate free radicals produced by metabolism. Our study identified that ZnAA beneficially enhanced CuZn-SOD activity in weaned piglets.

Safety evaluation is crucial for $\mathrm{Zn}$ additives. Prolonged addition of high-dose $\mathrm{Zn}$ oxide has been reported to be toxic to the liver in pigs [32]. Therefore, it is necessary to investigate the safety of $\mathrm{ZnAA}$ in piglets. Hematological parameters are a set of basic blood test indicators and are closely associated with systemic metabolic status; thus can be effective in assessing body health conditions [33]. Serum biochemical parameters, serum ALP, AST, and ALT activities, can reflect the metabolic status of liver and kidney, closely associating with the growth performance of pigs [34]. In experiment 2, the serum ALP activity in pigs fed 80 or $800 \mathrm{mg} / \mathrm{kg} \mathrm{Zn}$ as ZnAA were significantly higher than the pigs fed the unsupplemented diet at $\mathrm{d} 14$ and $\mathrm{d} 28$. The serum ALP activity in pigs fed diets containing $800 \mathrm{mg} \mathrm{Zn/kg} \mathrm{as} \mathrm{ZnAA} \mathrm{was} \mathrm{similar} \mathrm{to} \mathrm{the} \mathrm{serum} \mathrm{ALP}$ of pigs fed $80 \mathrm{mg} / \mathrm{kg} \mathrm{Zn}$ as $\mathrm{ZnAA}$. This indicates that a high dose of ZnAA may be well tolerated by weaned pigs considering the lack of difference in growth performance, hematological parameters and serum biochemical parameters between 80 and $800 \mathrm{mg} / \mathrm{kg}$ supplemental $\mathrm{Zn}$ as ZnAA.

\section{CONCLUSION}

Our results demonstrated that $\mathrm{ZnAA}$ (40 to $80 \mathrm{mg} / \mathrm{kg}$ ) is an efficient $\mathrm{Zn}$ supplement to promote the growth performance in weanling pigs. The piglets can tolerate up to $800 \mathrm{mg} / \mathrm{kg} \mathrm{Zn}$ from ZnAA with limited potential health effects.

\section{CONFLICT OF INTEREST}

We certify that there is no conflict of interest with any financial organization regarding the material discussed in the manuscript. Ward TL is an employee of Zinpro Corporation, and Ji F is an employee of Zinpro (Wuxi) Additives Bio-Technology Co., LTD.

\section{ACKNOWLEDGMENTS}

All authors are grateful for the help in laboratory analysis by staff of Ministry of Agriculture Feed Industry Centre. We thank Drs. Lee Jay Johnston and Crystal Levesque for editing this manuscript.

\section{REFERENCES}

1. Romeo A, Vacchina V, Legros S, et al. Zinc fate in animal husbandry systems. Metallomics 2014;6:1999-2009.

2. Hara T, Takeda TA, Takagishi T, et al. Physiological roles of zinc transporters: molecular and genetic importance in zinc homeostasis. J Physiol Sci 2017;67:283-301.

3. Nielsen FH. History of zinc in agriculture. Adv Nutr 2012;3: 783-9.

4. Hojyo S, Fukada T. Roles of zinc signaling in the immune system. J Immunol Res 2016;2016:Article ID 6762343.

5. Tucker HF, Salmon WD. Parakeratosis or zinc deficiency disease in the pig. Proc Soc Exp Biol Med 1955;88:613-6.

6. She Y, Li D, Zhang S. Methodological aspects of determining phosphorus digestibility in swine: a review. Anim Nutr 2017;3: 97-102.

7. Bergeron N, Robert C, Guay F. Feed supplementation with arginine and zinc on antioxidant status and inflammatory response in challenged weanling piglets. Anim Nutr 2017;3: 236-46.

8. NRC. Nutrient Requirements of Swine. 11th ed., Washington, DC, USA: National Academy Press; 2012.

9. EFSA Panel on Additives and Products or Substances used in Animal Feed (EFSA FEEDAP Panel). Scientific opinion on the potential reduction of the currently authorised maximum zinc content in complete feed. EFSA J 2014;12:3668.

10. Questions and answers on veterinary medicinal products containing zinc oxide to be administered orally to food-producing species [Internet]. London, UK: European Medicine Agency [cited 2017 Nov 10]. Available from: http:// www.ema.europa.eu/ema/index.jsp?curl=pages/medicines/ veterinary/referrals/Zinc_oxide/vet_referral_000122.jsp\&mid $=$ WC0b01ac05805c5170\#

11. Announcement No. 1224 [Internet]. Beijing, China: Ministry of Agriculture of People's Republic of China on June 18, 2009 [cited 2017 Nov 10]. Available from: http://www.moa.gov. cn/zwllm/tzgg/gg/200907/t20090706_1305167.htm

12. Acda SP, Chae BJ. A review on the application of organic trace minerals in pig nutrition. Pak J Nutr 2002;1:25-30.

13. Swinkels JW, Kornegay ET, Verstegen MW. Biology of zinc and biological value of dietary organic zinc complexes and chelates. Nutr Res Rev 1994;7:129-49.

14. Spears JW. Zinc methionine for ruminants: relative bioavilablity of zinc in lambs and effects of growth and performance of growing heifers. J Anim Sci 1989;67:835-43.

15. Rupić V, Svjetlana L, Ivana Č, et al. Calcium, phosphorus, zinc and their ratios in serum of fattening swine fed different diets in respect to zinc. Acta Vet 2004;54:175-89.

16. Feng M, Wang ZS, Zhou AG, Ai DW. The effects of different sizes of nanometer zinc oxide on the proliferation and cell integrity of mice duodenum-epithelial cells in primary culture. Pak J Nutr 2009;8:1164-6.

17. Wang Y, Tang JW, Ma WQ, et al. Dietary zinc glycine chelate on growth performance, tissue mineral concentrations, and 
serum enzyme activity in weanling piglets. Biol Trace Elem Res 2010;133:325-34.

18. Nitrayova S, Windisch W, von Heimendahl E, et al. Bioavailability of zinc from different sources in pigs. J Anim Sci 2012; 90(Suppl 4):185-7.

19. Han XY, Ma YF, Lv MY, et al. Chitosan-zinc chelate improves intestinal structure and mucosal function and decreases apoptosis in ileal mucosal epithelial cells in weaned pigs. Br J Nutr 2014;111:1405-11.

20. Paulicks BR, Ingenkamp H, Eder K. Bioavailability of two organic forms of zinc in comparison to zinc sulphate for weaning pigs fed a diet composed mainly of wheat, barley and soybean meal. Arch Anim Nutr 2011;65:320-8.

21. Guideline for Tolerance Evaluation of Feed Additives in Livestock and poultry [Internet]. Beijing, China: Ministry of Agriculture of P. R. China, on Jun 17, 2011 [cited 2017 Nov 10]. Available from: http://www.moa.gov.cn/govpublic/XMYS/ 201107/t20110720_2064934.htm

22. van Heugten E, Spears JW, Kegley EB, et al. Effects of organic forms of zinc on growth performance, tissue zinc distribution, and immune response of weanling pigs. J Anim Sci 2003;81: 2063-71.

23. Wedekind KJ, Hortin AE, Baker DH. Methodology for assessing zinc bioavailability: Efficacy estimates for zinc-methionine, zinc sulfate, and zinc oxide. J Anim Sci 1992;70:178-87.

24. Lee SH, Choi SC, Chae BJ, et al. Evaluation of metal-amino acid chelates and complexes at various levels of copper and zinc in weanling pigs and broiler chicks. Asian-Australas J Anim Sci 2001;14:1734-40.

25. Notice of the Ministry of Agriculture on Revising the Standards on Safety of feed additives [Internet]. ]. Beijing, China: Ministry of Agriculture of People's Republic of China on Sept 8, 2017 [cited 2017 Nov 10]. Available from: http://www.moa.gov.cn/ zwllm/zqyj/201709/t20170908_5809600.htm

26. Seal CJ, Heaton FW. Chemical factors affecting the intestinal absorption of zinc in vitro and in vivo. Br J Nutr 1983;50:317-24.

27. Lee SH, Choi SC, Chae BJ, et al. Effects of feeding different chelated copper and zinc sources on growth performance and fecal excretions of weanling pigs. Asian-Australas J Anim Sci 2001;14:1616-20.

28. Carlson D, Beattie JH, Poulsen HD. Assessment of zinc and copper status in weaned piglets in relation to dietary zinc and copper supply. J Anim Physiol Anim Nutr 2007;91:19-28.

29. Sun JY, Jing MY, Weng XY, et al. Effects of dietary zinc levels on the activities of enzymes, weights of organs, and the concentrations of zinc and copper in growing rats. Biol Trace Elem Res 2005;107:153-65.

30. Wedekind KJ, Lewis AJ, Giesemann MA, et al. Bioavailability of zinc from inorganic and organic sources for pigs fed cornsoybean meal diets. J Anim Sci 1994;72:2681-9.

31. Hahn JD, Baker DH. Growth and plasma zinc responses of young pigs fed pharmacologic levels of zinc. J Anim Sci 1993; 71:3020-4.

32. Jensen-Waern M, Melin L, Lindberg R, et al. Dietary zinc oxide in weaned pigs-effects on performance, tissue concentrations, morphology, neutrophil functions and faecal microflora. Res Vet Sci 1998;64:225-31.

33. AL-Shinnawy MS. Physiological effect of a food additive on some hematological and biochemical parameters of male albino rats. Egypt Acad J Biol Sci 2009;2:143-51.

34. Yablanski T. Lordation between the activity of the plasma enzyme GOT, GPT, AKP and some performance qualities in pigs. Col Sci Work 1986;30:599-616. 